\title{
Preparation and Characterization of Calcium Cross-Linked Starch Monolithic Cryogels and Their Application as Cost-Effective Green Filters
}

\author{
Chanita Boonkanon ${ }^{1}(\mathbb{D})$, Kharittha Phatthanawiwat ${ }^{1}$, Laemthong Chuenchom ${ }^{2} \mathbb{D}$, Nareumon Lamthornkit ${ }^{1}$, \\ Tarawee Taweekarn ${ }^{1}$, Worawit Wongniramaikul ${ }^{1}$ and Aree Choodum ${ }^{1, * \mathbb{D}}$
}

1 Integrated Science and Technology Research Center, Faculty of Technology and Environment, Prince of Songkla University, Phuket Campus, Kathu, Phuket 83120, Thailand; chanitanbkn@gmail.com (C.B.); kharittha.p@gmail.com (K.P.); jar.nareumon@gmail.com (N.L.); T.tarawee@hotmail.com (T.T.); worawit.won@phuket.psu.ac.th (W.W.)

2 Division of Physical Science and Center of Excellence for Innovation in Chemistry, Faculty of Science, Prince of Songkla University, Hat Yai Campus, Hat Yai, Songkhla 90110, Thailand; laemthong.c@psu.ac.th

* Correspondence: aree.c@phuket.psu.ac.th; Tel.: +66-(0)-7627-6481

Citation: Boonkanon, C.; Phatthanawiwat, K.; Chuenchom, L.; Lamthornkit, N.; Taweekarn, T.; Wongniramaikul, W.; Choodum, A. Preparation and Characterization of Calcium Cross-Linked Starch Monolithic Cryogels and Their Application as Cost-Effective Green Filters. Polymers 2021, 13, 3975. https://doi.org/10.3390/ polym13223975

Academic Editor: Shinichi Sakurai

Received: 15 October 2021

Accepted: 13 November 2021

Published: 17 November 2021

Publisher's Note: MDPI stays neutral with regard to jurisdictional claims in published maps and institutional affiliations.

Copyright: (C) 2021 by the authors Licensee MDPI, Basel, Switzerland. This article is an open access article distributed under the terms and conditions of the Creative Commons Attribution (CC BY) license (https:// creativecommons.org/licenses/by/ $4.0 /)$.

\begin{abstract}
Monolithic cryogels from starch were successfully synthesized and applied as alternative biodegradable filters for the first time. Rice flour was cross-linked with $\mathrm{Ca}^{2+}$ from limewater during gelatinization before being frozen and then thawed for three cycles. The resultant material was then soaked in ethanol for $3 \mathrm{~h}$ before incubation at $80^{\circ} \mathrm{C}$ for $1 \mathrm{~h}$, yielding monolithic material with interconnected pores in sizes of $51 \pm 18$ to $52 \pm 15 \mu \mathrm{m}$ without any need of freeze-drying. The cryogels possessed macroporous structure with specific surface areas from 1.1 to $4.3 \mathrm{~m}^{2} \mathrm{~g}^{-1}$, they could adsorb water from $599 \pm 27$ to $635 \pm 59 \%$ of their dry weight with low swelling ratios of $6.0 \pm 0.3$ to $6.4 \pm 0.6 \mathrm{~g}_{\text {water }} / \mathrm{g}_{\text {cryogel }}$, and could be applied as biofilters to remove suspended particles and reduce the light absorption of water sample from $25 \pm 3$ to $96 \pm 5 \%$. The prepared biofilters can be re-used up to three times, although they cost only USD 0.0004/piece. Complete weight loss resulted from burial in soil for 30 days, indicating environmentally friendly biodegradation and potential for environmental applications.
\end{abstract}

Keywords: starch; limewater; biodegradable cryogel; biodegradable filter; macropore

\section{Introduction}

Cryogels are cryogenically-structured polymeric materials, and have been used in biomedical [1,2], cell and tissue engineering [3], and environmental [4] applications; they are macroporous materials with a three-dimensional flexible structure, allowing for the effective mass transport of macromolecular solutes or migration of cells with high biocompatibility $[5,6]$. High water retention capacity can also be achieved, which is beneficial for aqueous phase applications. This type of material also has open-ended pores interconnected to form flow channels that facilitate fast diffusion, resulting in a fast response without any limitations or backpressure even in a high-flow-rate application [4]. Cryogels are also highly elastic and strong even under large deformations. They can be repeatedly compressed by at least $50 \%$ from their initial volume, without serious damage to the porous structure, because of their good mechanical stability [6-8].

Cryogels are synthesized from appropriate monomers or polymeric precursors via a freeze thawing technique (known as cryogelation, cryotropic gelation, or cryostructuration $[5,6,9,10])$. The gel precursors (monomers, cross-linkers, and initiators) induce either physical or chemical crosslinking in semi-frozen liquid medium at temperatures between $-5{ }^{\circ} \mathrm{C}$ and $-20{ }^{\circ} \mathrm{C}$, wherein the ice crystals act as porogens and thus as templates for the shape and size of the interconnected pores seen after thawing [6], i.e., the mixture 
consists of two main parts during freezing: the ice crystals, and a liquid microphase between the ice crystals. The chemical reaction (cross-linking) takes place in the non-frozen liquid microphase [11], resulting in the formation of relatively thin nano/microporous walls $[9,12,13]$, while the ice crystals continue to grow and merge with other crystals until a complete frozen frame of interconnected ice crystals is formed. The growth of the ice crystals can cause significant pressure on the formed pore walls typically making the walls relatively thin with low nano/microporosity [5]. Thus, the main stage of cryogel production is in the frozen state with gelation (cross-linking) at temperatures between -5 and $-20^{\circ} \mathrm{C}$. The gelation temperature affects the pore size distribution of the obtained cryogel, while the type and composition of the cross-linker affect the swelling degree of the material [6]. The freezing rate can also affect the final properties, i.e., a slower rate tends to give larger pores with increased interconnectivity, while a faster freezing rate produces mechanically weaker cryogel with a low level of interconnectivity due to supercooling of the solvent before ice crystals begin to form, yielding small, irregular pores [14]. Changes in the amount of water and organic co-solvent, as well as ionic strength, $\mathrm{pH}$, freeze thaw cycle, other precursor components, and polymerization conditions, also cause significant variations in the structural characteristics of the obtained cryogel [12,13]. However, the pore size has been reported to be the property most affected by these changes [10]. After having been frozen for an appropriate time, the material is allowed to thaw at room temperature, making the ice crystals melt and leaving an interconnected macroporous structure that is sponge-like and mechanically stable. The total pore volume of the native cryogels can be huge, up to $20-40 \mathrm{~cm}^{3} / \mathrm{g}[9,12,13]$, while the macropore walls (typically $1-10 \mu \mathrm{m}$, rarely $15-50 \mu \mathrm{m}$ in thickness) can include both nanopores $\left(\mathrm{d}_{\text {nano }}<0.1 \mu \mathrm{m}\right)$ and micropores $\left(\mathrm{d}_{\text {micro }}>0.1 \mu \mathrm{m}\right)[5]$.

Various polymeric precursors have been reported for cryogel preparation $[3,5,6]$. Both natural and synthetic polymers can be used to produce cryogels with different morphologies and porosities $[3,5,6]$. Synthetic polyvinyl alcohol (PVA) is the first and the most popular polymer that has been used for cryogel preparation, both alone and in combination with other polymers $[5,15,16]$. This is because its structure containing $\left(-\mathrm{CH}_{2}-\mathrm{C}(\mathrm{OH}) \mathrm{H}-\right)_{\mathrm{n}}$ chains, allows for various degrees of cross-linking with the participation of the active $\mathrm{COH}$ groups, along with various cross-linkers and co-polymers. Other synthetic polymers have also been reported, such as poly(vinyl pyrrolidone) (PVP) [15], poly(4-vinyl pyridine) [17], and Jeffamine diamino hexane [18]. Natural polymers are sometimes a good choice as they tend to have low toxicity and good biocompatibility. Proteins, e.g., collagen and gelatin, are popular precursors for the preparation of cryogels because of their great biocompatibility and significant functionalization. Spongy collagen and gelatin cryogels can be prepared via cross-linking with dialdehyde starch [19-23]. Biocompatible polysaccharides and related compounds, e.g., chitosan or hyaluronic acid, have also been reported [24-26]. They have numerous hydroxyls and other functionalities with $\mathrm{O}$ and $\mathrm{N}$ atoms similar to PVA, but with more complex structure of cyclic monomers. Agarose-alginate cryogels have also been synthesized in different shapes such as monoliths, sheets, discs, and beads with mechanical strength similar to soft natural tissues [27]. Physically and chemically cross-linked cellulose cryogels have also been reported using epichlorohydrin as a cross-linker [28]. PVA has also been combined with microcrystalline cellulose [29]. Starch is one of the most promising precursors for cryogel preparation because of its low cost, abundant supply, good processability, biodegradability, and ease of chemical modifications [30,31]. It is commonly used together with synthetic polymers, e.g., N,N-dimethylaminoethyl methacrylate [30], glycidyl methacrylate [32] and polyacrylamide [31,33] due to a lack of functional groups for cross-linking [32]. Recently, cryogels from waxy starch have been prepared without any additional synthetic polymers, however freeze drying at $-82{ }^{\circ} \mathrm{C}$ [34] or at $-150{ }^{\circ} \mathrm{C}$ [35] was required.

In this work, an alternative procedure for the greener preparation of macroporous monolithic (single-rod) cryogels using starch is reported. The procedure to prepare the Thai dessert "Lod-chong" was modified to prepare a novel single-rod cryogel from rice 
flour without any additional synthetic polymers. The gel precursor was prepared via gelatinization of rice flour in the presence of calcium ions from alkaline limewater (calcium hydroxide solution commonly used as a functional ingredient to give cohesiveness and firmness to traditional desserts [36]) that act as cross-linkers. The gelatinized starch was then subjected to a conventional freeze thaw technique (at $-18{ }^{\circ} \mathrm{C}$ ) instead of freezedrying at $-82{ }^{\circ} \mathrm{C}$ or at $-150{ }^{\circ} \mathrm{C}$ as reported previously $[34,35]$ to produce the cryogel. The morphology, porosity, water uptake capability, water retention, and biodegradability of the prepared cryogels were tested. The novel cryogels prepared via the alternative procedure reported in this work for the first time were then applied as filters for water samples with satisfactory preliminary results.

\section{Materials and Methods}

\subsection{Materials}

Rice flour (Erawan Brand, Nakhon Pathom, Thailand) was locally purchased from a supermarket; its amylose content was analyzed using a spectrophotometer, with reference to Thai agriculture standard TAS 4000-2003 (in-house method TE-PH-021, based on Quality and Testing of Thai Horm Mali Rice, 2004, Department of Agriculture, Bangkok, Thailand), and $23.3 \%$ amylose was found. Red lime (RL) and white lime (WL) (no brand, food grade) were also bought from a supermarket in Phuket, Thailand. It is worth noting that WL is calcium hydroxide, which is commonly prepared by adding water to $\mathrm{CaO}$, while RL is the mixture of WL with curcumin. Calcium hydroxide was supplied by ITW Reagents (Darmstadt, Germany). Ethanol (95\%), hydrochloric acid, and sodium hydroxide were purchased from Merck (Darmstadt, Germany). Ultrapure water was obtained using a water purification system (Merck, Darmstadt, Germany).

\subsection{Preparation of Cryogels}

Calcium hydroxide solutions were prepared both in the form of limewater, which is commonly used in the preparation of Lod-chong noodles, and standard calcium hydroxide solution. Various compositions of calcium hydroxide solution were prepared by dissolving $0.08,0.16,0.24$, and $0.32 \% w / v$ of red lime (RL), white lime (WL), and calcium hydroxide standard $\left(\mathrm{Ca}(\mathrm{OH})_{2}\right)$ in ultrapure water as discussed in the Supplementary Materials (Figures S1-S4). The concentrations of $\mathrm{Ca}^{2+}$ in the solution is reported in Table 1.

Rice flour $(4,8,12$, and $16 \mathrm{~g}$ ) was dispersed in $60 \mathrm{~mL}$ of prepared limewater (clear solutions from RL and WL) as well as prepared $\mathrm{Ca}(\mathrm{OH})_{2}$ solution and heated (gradually increasing from 70 to $90{ }^{\circ} \mathrm{C}$ for $30 \mathrm{~min}$ ) until the starch was completely gelatinized and became clear. The gelatinized starch was cooled to room temperature under continued stirring for $5 \mathrm{~min}$. The homogeneous mixture was filled into $3 \mathrm{~mL}$ plastic syringes that were placed in a freezer at $-18{ }^{\circ} \mathrm{C}$ for $24 \mathrm{~h}$. The resultant monolith was then thawed at room temperature, and the freeze thaw cycles were appropriately repeated (for 1-7 cycles). The obtained single-rod cryogel was then removed from the container and cut into smaller pieces ( $\sim 1 \mathrm{~cm}$ in length); they were soaked in $95 \%$ ethanol for an appropriate time $(1,2,3,6$, 12,18 , and $24 \mathrm{~h}$ ) before incubation in an oven at an appropriate temperature $(60,80$, and $\left.100^{\circ} \mathrm{C}\right)$ and for various times $(20,40,60$, and $90 \mathrm{~min})$. All dried cryogels were stored in zip-lock plastic bags and placed in a desiccator until further use.

\subsection{Characterization of Cryogels}

The morphology of the cryogels was investigated using field emission scanning electron microscopy (FE-SEM; FEI, Brno, Czech Republic). The samples were sputter coated with a thin film of gold under vacuum before imaging. The functional groups of cryogels, red lime paste, and white lime paste were analyzed with Fourier transform infrared spectroscopy (FT-IR; Bruker, Berlin, Germany) using KBr pellet and ATR technique at 4000-600 $\mathrm{cm}^{-1}$. X-ray diffraction (XRD) patterns were analyzed with X-ray diffractometer (Empyrean, Panalytical, Almelo, Netherlands) under monochromatic $\mathrm{Cu} \mathrm{K} \alpha$ radiation. The surface area and porosity were determined from nitrogen adsorption/desorption isotherms 
using a high throughput surface area and porosity analyzer (ASAP2460, Micromeritics, GA, USA) at $77 \mathrm{~K}$. The prepared cryogels were degassed at $105^{\circ} \mathrm{C}$ for $30 \mathrm{~min}$ to remove physically absorbed gases from the sample surface before analysis. The specific surface area $\left(\mathrm{S}_{\mathrm{BET}}\right)$ was estimated using the Brunauer-Emmet-Teller (BET) method, while the pore volume was obtained from determination using $\mathrm{P} / \mathrm{P}_{0}$ of 1 . The average pore diameter was calculated using the Barrett-Joyner-Halenda (BJH) method.

\subsection{Swelling Ratio, Water Uptake Capacity, Water Retention, and Porosity of Cryogels}

The swelling ratio and water retention of cryogels were investigated as described in prior reports $[37,38]$. The swelling ratio was calculated by weighing the dried and wet cryogels. Three completely dried cryogels of similar size $(0.8 \mathrm{~mm} \times 1 \mathrm{~cm}$ length $)$ and weight $(\sim 0.1 \mathrm{~g})$ were equilibrated in $30 \mathrm{~mL}$ of ultrapure water at ambient temperature. The water-absorbed cryogels were weighed after removing the surface excess water with filter paper at certain time intervals up to equilibrium (1 to $60 \mathrm{~min})$. The swelling ratio $\left(\mathrm{S}_{\mathrm{g}} / \mathrm{g}\right)$ was calculated using Equation (1) [37,38], where $W_{t}$ is the weight of swollen cryogel at the time of observation and $\mathrm{W}_{0}$ is the weight of dried cryogel. The swelling behavior of the cryogel was analyzed at $\mathrm{pH}$ values ranging from 2 to 13 , and at various temperatures (20, $30,40,50$, and $60^{\circ} \mathrm{C}$ ).

$$
\text { Swelling ratio }\left(\mathrm{S}_{\mathrm{g} / \mathrm{g}}\right)=\frac{\left(\mathrm{W}_{t}-\mathrm{W}_{0}\right)}{\mathrm{W}_{0}}
$$

The water uptake capacity (\%) was calculated using Equation $(2)[37,38]$ where $\mathrm{W}_{e}$ is the weight of swollen cryogel at equilibrium. The 24-h water uptake capacity was also determined by immersing the cryogel in distilled water at room temperature for $24 \mathrm{~h}$. The average weights of three cryogels before $\left(\mathrm{W}_{0}\right)$ and after testing $\left(\mathrm{W}_{24-h}\right)$ were investigated, and the percentage of water uptake capacity (Absorbency) was calculated using Equation (3) [33]:

$$
\begin{gathered}
\text { Water uptake capacity }(\%)=100 \times \frac{\left(\mathrm{W}_{t}-\mathrm{W}_{0}\right)}{\left(\mathrm{W}_{e}-\mathrm{W}_{0}\right)} \\
\text { Absorbency }(\%)=100 \times \frac{\left(\mathrm{W}_{24-h}-\mathrm{W}_{0}\right)}{\mathrm{W}_{0}}
\end{gathered}
$$

The equilibrated cryogels were then put in Petri dishes at room temperature and re-weighed at specific times. The weights of the cryogels $\left(\mathrm{W}_{T}\right)$ were recorded during the course of deswelling until they had reached steady levels. The water retention (\%) can be calculated using Equation (4) [37]:

$$
\text { Water retention }(\%)=100 \times \frac{\left(\mathrm{W}_{T}-\mathrm{W}_{0}\right)}{\left(\mathrm{W}_{e}-\mathrm{W}_{0}\right)}
$$

The porosity of the cryogels (\%) was also determined by squeezing the swollen gels, using Equation (5) [6]. The weight of swollen gel $\left(\mathrm{W}_{e}\right)$ was compared to the weight after squeezing $\left(\mathrm{W}_{q}\right)$.

$$
\text { Porosity }(\%)=100 \times \frac{(\mathrm{We}-\mathrm{W} q)}{\mathrm{We}}
$$

\subsection{Application of Cryogels as Biofilters}

The $0.32 \% \mathrm{RL}$ and $0.16 \% \mathrm{Ca}(\mathrm{OH})_{2}$ cryogels were preliminarily tested as biofilters for four surface water samples randomly collected from Phuket, Thailand and one soil extract available in the laboratory. The ultrapure water $(4 \mathrm{~mL})$ was first loaded with gravity flow through the biofilters before loading a $4 \mathrm{~mL}$ water sample. The light absorption spectra of each sample were scanned $(200-800 \mathrm{~nm})$ before and after filtration for comparison. The filters were then cleaned by flushing in the reverse flow direction, before being washed with ultrapure water $(10 \mathrm{~mL})$ and then re-used to test their reusability. 


\section{Results and Discussion}

\subsection{Preparation of Cryogels}

Monolithic cryogels based on native starch were synthesized by modifying the procedure for the preparation of Lod-chong as shown in the Supplementary Materials (Figure S5). When calcium hydroxide solutions ( $\mathrm{pH} \sim 12$ ) were mixed with starch and gelatinized, the $\mathrm{pH}$ decreased in all cases of calcium hydroxide solutions ( $\mathrm{pH} \sim 11$; Supplementary Materials, Figure S3) due to the binding between $\mathrm{Ca}^{2+}$ or $\mathrm{Ca}(\mathrm{OH})^{+}$and flour [39]. After stopping the heating but still mixing with the starch, the $\mathrm{pH}$ of the mixture reached its maximum at concentrations higher than those for the solutions. Apparently, some hydroxyl groups of starch were oxidized at high $\mathrm{pH}$ making sites for interactions with the $\mathrm{Ca}^{2+}$ or $\mathrm{Ca}(\mathrm{OH})^{+}$ from dissociated $\mathrm{Ca}(\mathrm{OH})_{2}$, thereby shifting the equilibrium and allowing for greater solubilization of lime $[39,40]$. Thus, the results indicate that limewater acts as a cross-linker for ionic cross-linking of starch in a gelatinized state and this tightens the starch chains [41].

The obtained single-rod macroporous material $(6 \mathrm{~cm}$ in length) can be cut to the desired length for further application (Figure 1a). Although the cryogel from ultrapure water was similar in appearance to all types of calcium hydroxide solution, it was damaged after applying compression matching previous reports stating that better elasticity and plasticity have been found for the starch gel with $\mathrm{Ca}^{2+}$ due to the effects of $\mathrm{Ca}^{2+}$ on the physicochemical properties of starch [42]. Without $\mathrm{Ca}^{2+}$ ions in acidic condition (pH 5.4 to 5.5), no ionic cross-linking occurred resulting in a weaker gel; thus, the ice crystals could easily push aside the pore walls to connect with nearby crystals, thus leaving larger pores oriented in the direction of the ice growth after cryogenic treatment [43], as shown in Figure $1 b$.

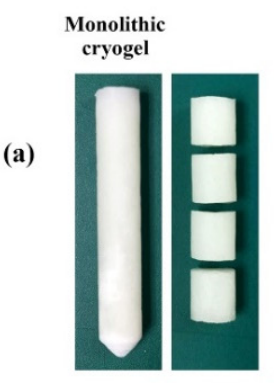

(b)

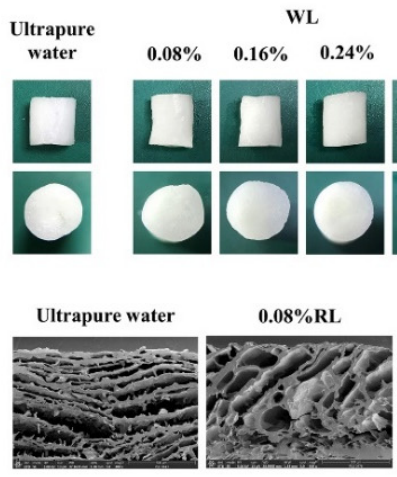

WL
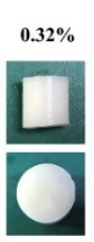

$0.08 \% \quad 0.16 \% \quad 0.24 \% \quad 0.32 \%$

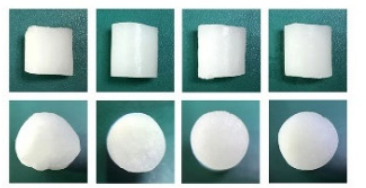

$0.16 \% R L$

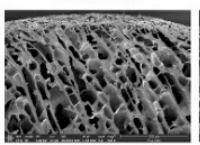

$0.24 \% \mathrm{RL}$

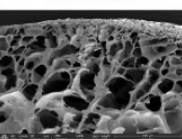

$0.32 \%$ RL

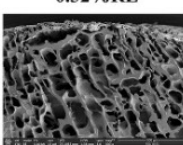

$\mathrm{Ca}(\mathrm{OH})_{2}$ $0.08 \% \quad 0.16 \% \quad 0.24 \% \quad 0.32 \%$

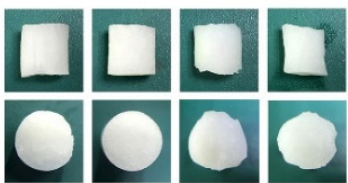

$0.32 \% \mathrm{WL}$

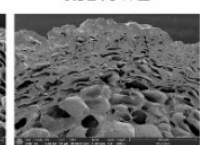

$0.32 \% \mathrm{Ca}(\mathrm{OH})_{2}$

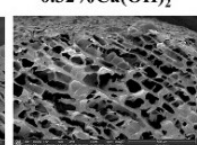

Figure 1. (a) The cryogels obtained with various amounts of red lime (RL), white lime (WL) and calcium hydroxide standard solution $\left(\mathrm{Ca}(\mathrm{OH})_{2}\right)$ prepared using the limewater on the day of its preparation with one freeze-thaw-cycle, and $(\mathbf{b})$ their FE-SEM images.

The cryogel prepared with $0.08 \%$ RL was damaged after compression, while preparation with a larger amount produced more resilient samples. Increased porosity and swelling ratio were obtained when increasing $\%$ RL from $0.16 \%$ to $0.32 \%$, as shown in Table 1. For limewater from WL, the cryogels synthesized with $0.08-0.24 \%$ WL were easy to damage by compression, and only the $0.32 \% \mathrm{WL}$ case recovered its shape and had similar porosity and swelling ratio to $0.32 \%$ RL although the concentration of calcium ions in $0.32 \%$ WL was lower than in $0.32 \% \mathrm{RL}$ (Table 1 ). The results indicate that not only $\mathrm{Ca}^{2+}$ ions play a role in cross-linking. In the case of cryogels prepared using standard calcium hydroxide solution, increasing the amount of $\mathrm{Ca}(\mathrm{OH})_{2}$ from $0.08 \%$ to $0.32 \%$ led to smaller pore size in the cryogels (Figure 2) due to the higher amount of $\mathrm{Ca}^{2+}$ providing more ionic cross-linking, producing a stronger network that could tolerate the pressure from ice crystals during freezing. However, the porosity of the $0.24 \%$ and $0.32 \% \mathrm{Ca}(\mathrm{OH})_{2}$ cases was below that of those prepared with a lower amount $(0.08 \%$ or $0.16 \%)$, and the same was true of the swelling ratios (Table 1). The cryogels from $0.08 \%$ and $0.16 \% \mathrm{Ca}(\mathrm{OH})_{2}$ could also recover their shape better, indicating higher elasticity than in the $0.24 \%$ and $0.32 \%$ cases; this may 
be due to a greater degree of cross-linking at higher concentration of calcium hydroxide solution, increasing the network density of the cryogel and resulting in a slow relaxation of the network chains, with reduced swelling and elasticity [44]. It is worth noting that the $\mathrm{pH}$ levels of the gel precursor during and after complete gelatinization with $0.32 \%$ $\mathrm{WL}, 0.32 \% \mathrm{RL}$, and $0.16 \% \mathrm{Ca}(\mathrm{OH})_{2}$ were similar (as seen in the Supplementary Materials, Figure S3), and this may influence the oxidation of the hydroxyl groups of starch, leading to the cryogels have similar properties despite the different concentrations of $\mathrm{Ca}^{2+}$ in the solutions.

$0.08 \% \mathrm{Ca}(\mathrm{OH})_{2}$

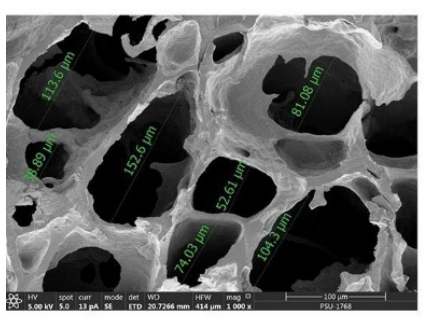

$0.16 \% \mathrm{Ca}(\mathrm{OH})_{2}$

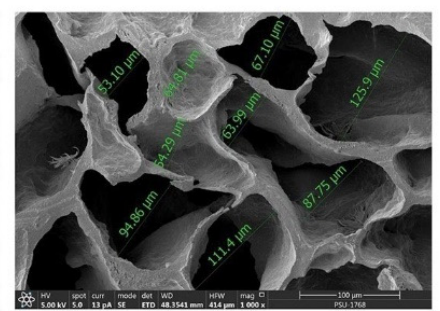

$0.24 \% \mathrm{Ca}(\mathrm{OH})_{2}$

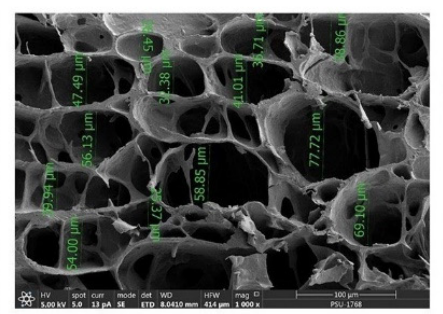

$0.32 \% \mathrm{Ca}(\mathrm{OH})_{2}$

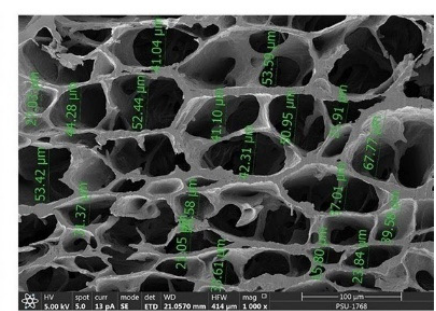

Figure 2. FE-SEM images of the cryogels prepared using various amounts of $\mathrm{Ca}(\mathrm{OH})_{2}$ in limewater prepared at least three days earlier and with three freeze thaw cycles.

Table 1. Porosity and swelling ratio of the cryogels $(n=3)$.

\begin{tabular}{|c|c|c|c|c|c|}
\hline $\begin{array}{c}\text { Type of } \\
\text { Cross-Linker }\end{array}$ & $\begin{array}{c}\text { Concentration of } \\
\text { Cross-Linker }(\% w / v) * * *\end{array}$ & $\begin{array}{l}\text { Concentration of } \\
\mathrm{Ca}^{2+}(\mathrm{mg} / \mathrm{L})^{*}\end{array}$ & $\begin{array}{l}\text { Recovers from } \\
\text { Compression ** }\end{array}$ & $\begin{array}{c}\text { Porosity } \\
(\%)\end{array}$ & $\begin{array}{c}\text { Swelling Ratio } \\
\left(\mathrm{S}_{\mathrm{g} / \mathrm{g}}\right)\end{array}$ \\
\hline WL & 0.08 & $117 \pm 5$ & No & - & - \\
\hline WL & 0.16 & $114 \pm 1$ & No & - & - \\
\hline WL & 0.24 & $112 \pm 0$ & No & - & - \\
\hline WL & 0.32 & $119 \pm 1$ & Yes & $51 \pm 4$ & $5.9 \pm 0.3$ \\
\hline $\mathrm{RL}$ & 0.08 & $176 \pm 0$ & No & - & - \\
\hline RL & 0.16 & $145 \pm 5$ & Yes & $19 \pm 2$ & $3.3 \pm 0.3$ \\
\hline RL & 0.24 & $403 \pm 12$ & Yes & $33 \pm 3$ & $4.2 \pm 0.4$ \\
\hline RL & 0.32 & $630 \pm 3$ & Yes & $52 \pm 6$ & $6.0 \pm 0.3$ \\
\hline $\mathrm{Ca}(\mathrm{OH})_{2}$ & 0.08 & $364 \pm 5$ & Yes & $39 \pm 2$ & $4.5 \pm 0.3$ \\
\hline $\mathrm{Ca}(\mathrm{OH})_{2}$ & 0.16 & $419 \pm 8$ & Yes & $51 \pm 2$ & $6.4 \pm 0.6$ \\
\hline $\mathrm{Ca}(\mathrm{OH})_{2}$ & 0.24 & $688 \pm 22$ & Yes & $32 \pm 8$ & $4.1 \pm 0.6$ \\
\hline $\mathrm{Ca}(\mathrm{OH})_{2}$ & 0.32 & $712 \pm 8$ & Yes & $28 \pm 1$ & $3.6 \pm 0.3$ \\
\hline
\end{tabular}

*: Analyzed by ICP-OES; ${ }^{* *}$ : while squeezing the swollen gel to investigate its porosity; ${ }^{* * *} \% w / v=\mathrm{g}$ of lime or $\mathrm{Ca}(\mathrm{OH})_{2}$ in $100 \mathrm{~mL}$ of solution.

Therefore, the results showed that limewater and calcium hydroxide solution used as the cross-linker affected the cryogels and the limewater from $0.32 \% \mathrm{RL}$ and $0.16 \% \mathrm{Ca}(\mathrm{OH})_{2}$ prepared at least three days ahead of use is recommended as it provided cryogels with good physical and mechanical properties and with the highest porosity. The limewater $(60 \mathrm{~mL})$ was used to disperse rice flour $(4,8,12$, and $16 \mathrm{~g})$ to prepare the gel precursor. The cryogels prepared from $4 \mathrm{~g}$ of starch were damaged after applying compression, while $8 \mathrm{~g}$ starch cryogels could tolerate the compression, indicating greater strength; this may have been due to the increased degree of cross-linking, resulting in smaller macropores in cryogels with higher porosity and better elasticity. However, further increasing rice flour to 12 and $16 \mathrm{~g}$ made the cryogels dense and they were damaged after applying compression. Leftover starch granules were also evidenced in the cryogels, which may indicate lack of sufficient water to swell the starch granules and access their internal structures for solubilization [45]. 
The influence of freeze thaw cycles on the cryogels was investigated, and the results are shown in the Supplementary Materials (Figure S6). When the number of freeze thaw cycles was increased, the pores of the cryogels seemed to grow from 1 to 3 cycles $(40 \pm 11$ to $51 \pm 18 \mu \mathrm{m}$; Figure $3 \mathrm{a}-\mathrm{c}$ ) and slightly grow after that (50 \pm 17 to $57 \pm 11 \mu \mathrm{m}$; Figure $3 \mathrm{f}-\mathrm{i}$ ). The cryogenic cycles also affected the porosity, which increased from 1 to 3 cycles and then remained constant from 4 to 7 cycles (Supplementary Materials, Figure S7). When compression was applied to the cryogels, no damage was observed to the material with three cycles, while those from one and two cycles were damaged. This corresponds to the results for noncovalent PVA cryogel, the strength of which increased with increasing the number of freeze thaw cycles, due to the growth of crystallinity in the PVA [46].
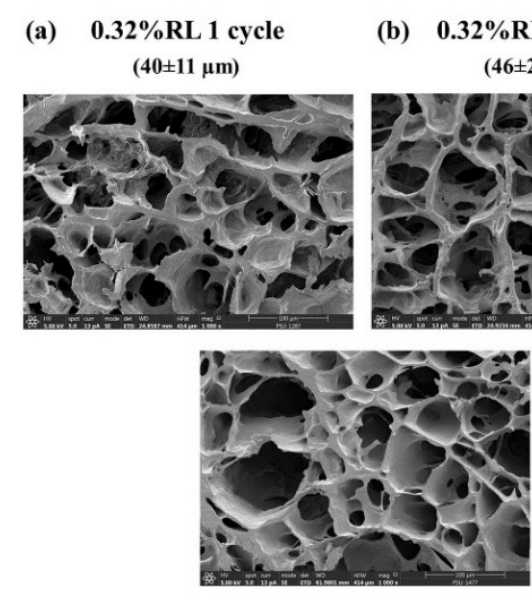

(f) $0.32 \% \mathrm{RL} 4$ cycles $(50 \pm 17 \mu \mathrm{m})$ (b) $0.32 \%$ RL 2 cycles $(46 \pm 24 \mu \mathrm{m})$ (c) $\quad 0.32 \% \mathrm{RL} 3$ cycles (51 $\pm 18 \mu \mathrm{m}, 8 \pm 2 \mu \mathrm{m}$ wall thicknes (d) $0.16 \% \mathrm{Ca}(\mathrm{OH})_{2} 3$ cycles ( $52 \pm 15 \mu \mathrm{m}, 8 \pm 2 \mu \mathrm{m}$ wall thickness) (e) Ultrapure water 3 cycles $(56 \pm 27 \mu \mathrm{m}, 17 \pm 10 \mu \mathrm{m}$ wall thickness )
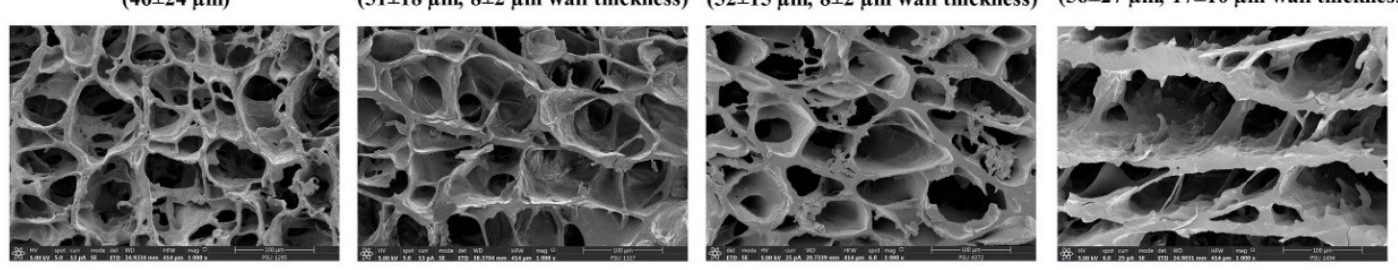

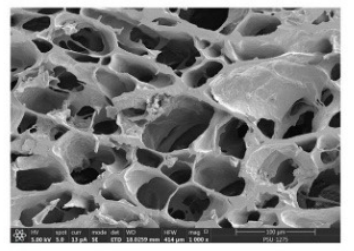

(g) $0.32 \% \mathrm{RL} 5$ cycles $(40 \pm 13 \mu \mathrm{m})$

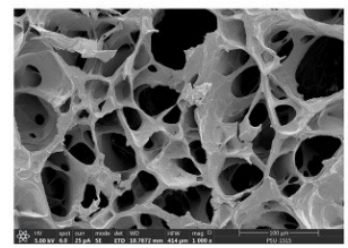

(h) $0.32 \%$ RL 6 cycles (53 $\pm 23 \mu \mathrm{m})$

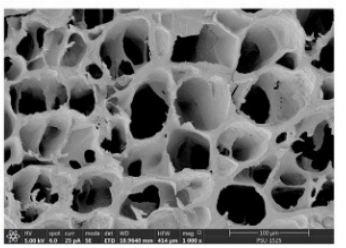

(i) $\quad 0.32 \% \mathrm{RL} 7$ cycles (57 $\pm 11 \mu \mathrm{m})$

Figure 3. FE-SEM images and average pore sizes of the cryogels prepared by using (a-c,f-i) $0.32 \%$ RL with $1-7$ freeze-thaw cycles, respectively (d) $0.16 \% \mathrm{Ca}(\mathrm{OH})_{2}$, and (e) ultrapure water with three freeze-thaw cycles under the optimal conditions.

Thus, an alternative procedure to prepare a monolithic macroporous cryogel from starch is reported as follows: Rice flour $(8 \mathrm{~g})$ was dispersed in $60 \mathrm{~mL}$ of limewater from $0.32 \% \mathrm{RL}$ or $0.16 \% \mathrm{Ca}(\mathrm{OH})_{2}$, prepared at least 3 days ahead of use. The gel precursor was gradually gelatinized before cooling down, and was tightly filled into a container, and then frozen at $-18{ }^{\circ} \mathrm{C}$ for $24 \mathrm{~h}$. The resultant monolith is then thawed at room temperature, and freeze thaw treatment was repeated for a total of three cycles. In this manner, a cryogel from starch can be prepared without the addition of any synthetic polymer.

The obtained single-rod cryogels were cut to appropriate sizes depending on their application before drying. When the cryogel was incubated without soaking in ethanol, it lost its shape (Supplementary Materials, Figure S8a, in the middle) due to pore collapse, which commonly occurs in porous materials [34]. The protection against pore collapse by ethanol dehydration may contribute to some degree of crystallization of starch, and hardened surfaces were creased during dehydration [10]. The FE-SEM images of the ethanol-dehydrated cryogel (Figure 3c,d) show thicker walls than in freeze-dried cryogel (Supplementary Materials, Figure S9) as the growth of ice crystals during the freeze-drying process could push aside the pore walls of the materials [34]. The dehydration time, incubation temperature, and incubation time are discussed in the Supplementary Materials (Figure S10). The porosity of the ethanol-dehydrated cryogels was higher than that of the freeze-dried cryogels (Supplementary Materials, Figure S11). The dried cryogels can be stored for at least 2 years, and can be re-conditioned by soaking in water for $10 \mathrm{~min}$ before use (Supplementary Materials, Figure S8b,c), i.e., the filters prepared on March 2019 can reduce the light absorption of the water sample (no. 5) at $290 \mathrm{~nm}$ with $-6.25 \%$ difference for $0.32 \% \mathrm{RL}$ and $-7.29 \%$ for $0.16 \% \mathrm{Ca}(\mathrm{OH})_{2}$ prepared in July, 2021. Thus, the cryogels prepared via the novel procedure reported in this work can be dried using a simple and 
easy process, i.e., ethanol dehydration coupled with incubation in oven for an appropriate time, instead of freeze drying.

The proposed mechanism is shown in Figure 4, and the FE-SEM images of the cryogels obtained under the optimal conditions are shown in Figure 3c,d. The pore sizes of the cryogels prepared from $0.32 \%$ RL $(\sim 51 \pm 18 \mu \mathrm{m})$ and $0.16 \% \mathrm{Ca}(\mathrm{OH})_{2}(\sim 52 \pm 15 \mu \mathrm{m})$ are smaller than those of cryogels synthesized without the cross-linker $(\sim 56 \pm 27 \mu \mathrm{m}$; Figure 3e), which were larger than those frozen in liquid nitrogen $\left(-196{ }^{\circ} \mathrm{C}, 2.5 \mu \mathrm{m}\right)$, but smaller than the macropores $(430.93 \mu \mathrm{m})$ formed in the freezer $\left(-15^{\circ} \mathrm{C}\right)$ [47]. The thickness of the walls of the cryogels synthesized without the cross-linker $(\sim 17 \pm 10 \mu \mathrm{m})$ was also the greatest $\left(\sim 8 \pm 2 \mu \mathrm{m}\right.$ for $0.32 \% \mathrm{RL}$ and $\left.0.16 \% \mathrm{Ca}(\mathrm{OH})_{2}\right)$; due to reduced interconnected polymerization of the network.

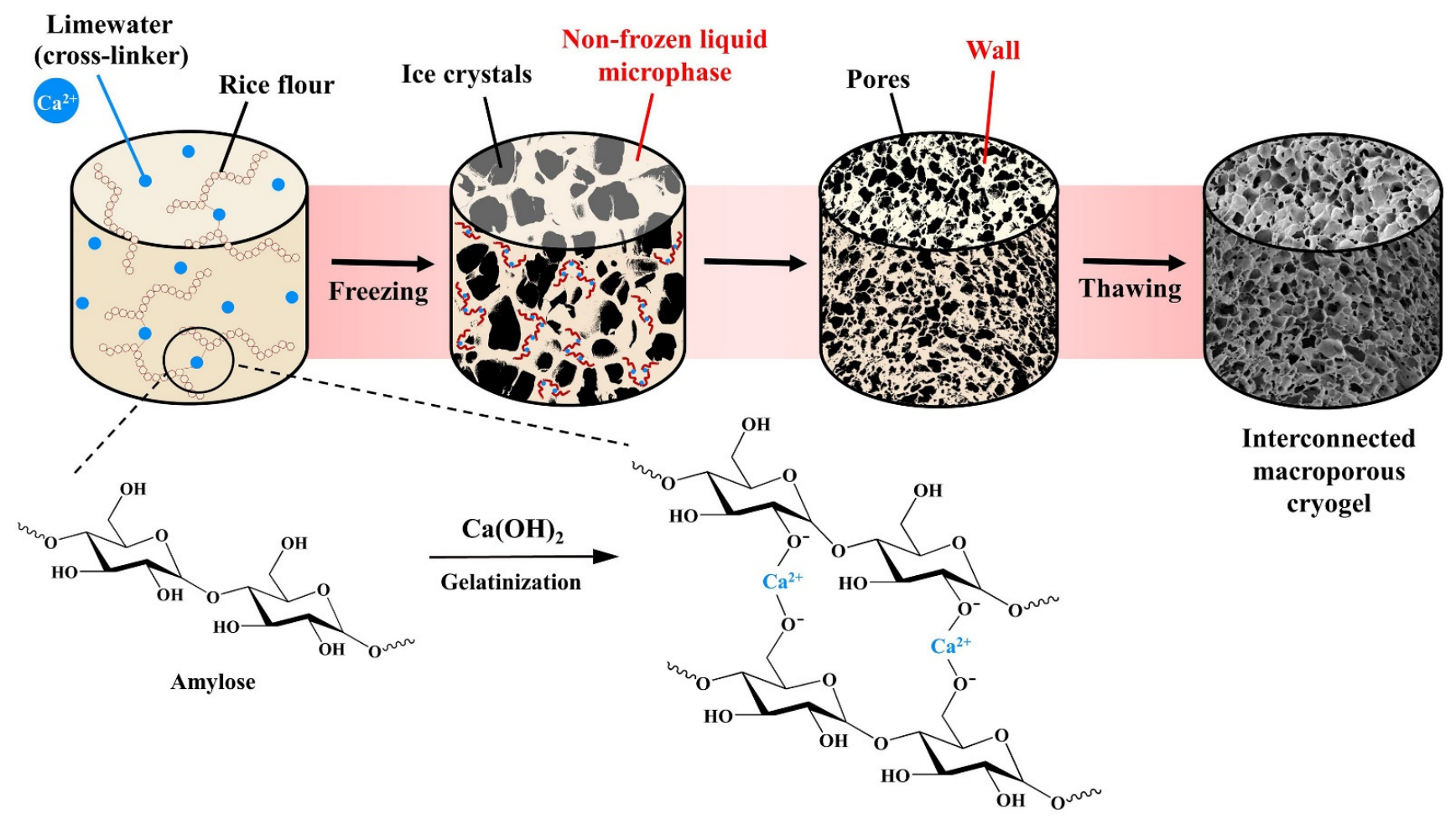

Figure 4. Proposed mechanism of synthesis of the cryogels.

\subsection{Characterization of Cryogels}

The adsorption-based average pore diameter from the BET analysis of $0.32 \% \mathrm{RL}$ $(5.6206 \AA)$ was larger than that of $0.16 \% \mathrm{Ca}(\mathrm{OH})_{2}(3.4121 \AA)$, with less specific surface area $\left(\mathrm{S}_{\text {BET }}\right)$ at $1.1177 \pm 0.0320 \mathrm{~m}^{2} \mathrm{~g}^{-1}\left(4.3117 \pm 0.1017 \mathrm{~m}^{2} \mathrm{~g}^{-1}\right.$ for $\left.0.16 \% \mathrm{Ca}(\mathrm{OH})_{2}\right)$. The $\mathrm{S}_{\text {BET }}$ matches other reports on a low surface area ( 3 to 13 [34] and 0.6 to $7.7 \mathrm{~m}^{2} \mathrm{~g}^{-1}$ [48]) for porous materials synthesized from native starch using freeze-drying. These results indicate that $0.32 \% \mathrm{RL}$ and $0.16 \% \mathrm{Ca}(\mathrm{OH})_{2}$ seem to be macroporous rather than meso- or microporous materials, matching the FE-SEM images showing $\sim 50 \mu \mathrm{m}$ pore size. Both prepared cryogels exhibited a typical type III adsorption isotherm (Figure $5 \mathrm{a}, \mathrm{b}$ ), as there was no steep uptake at low $\mathrm{P} / \mathrm{P}_{0}$ indicating that the $\mathrm{N}_{2}$ was adsorbed on the surface of the macroporous materials, with relatively weak interaction [49]. Opened loops were also observed for both cryogels, which could be attributed to several factors. Since cryogels prepared from starch do not have a rigid structure, they can deform (swell) during adsorption or pore filling. The trapped nitrogen also cannot be released due to the affinity of nitrogen in cryogels caused by the heterogeneity of the cryogel surface [50]. 
(a)

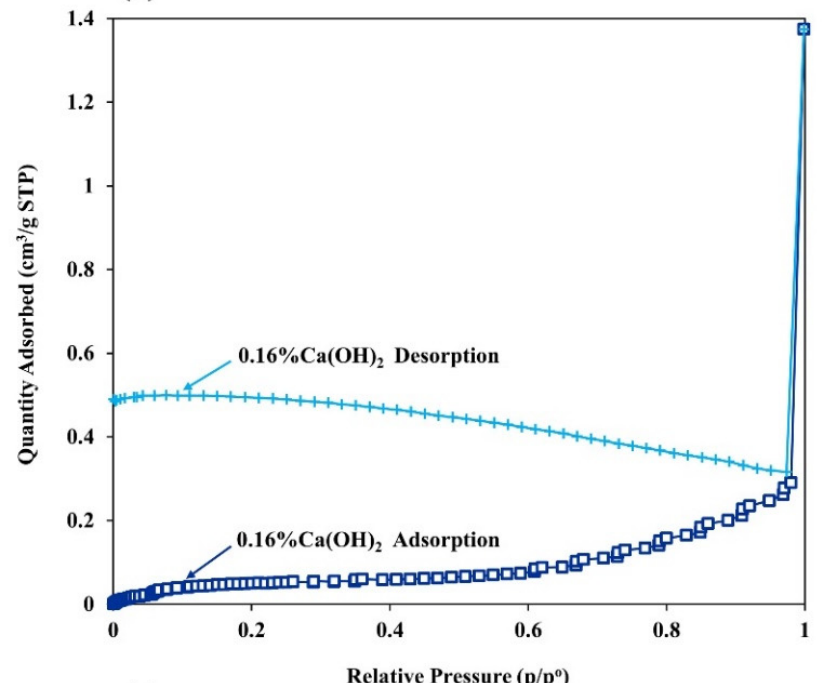

(c)

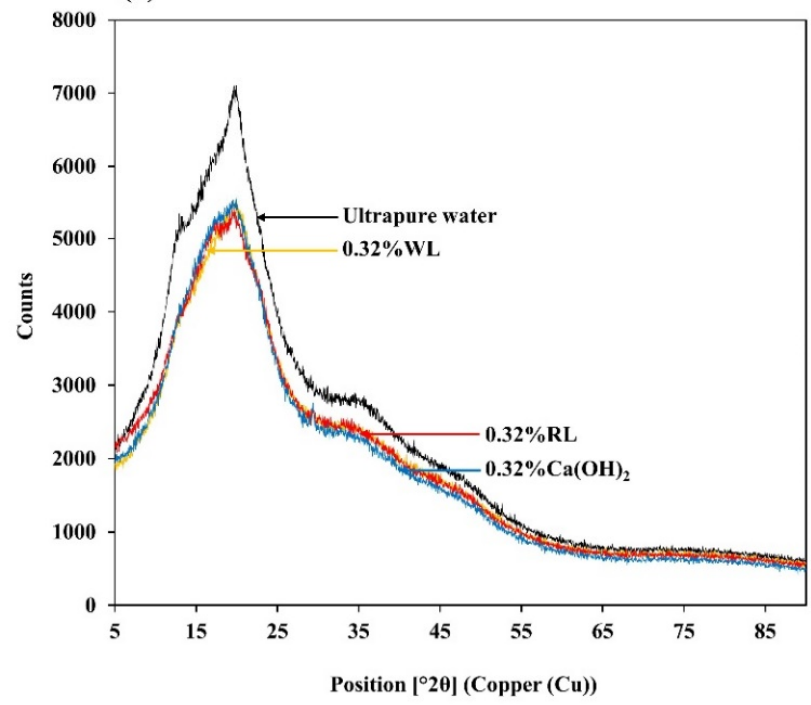

(b)

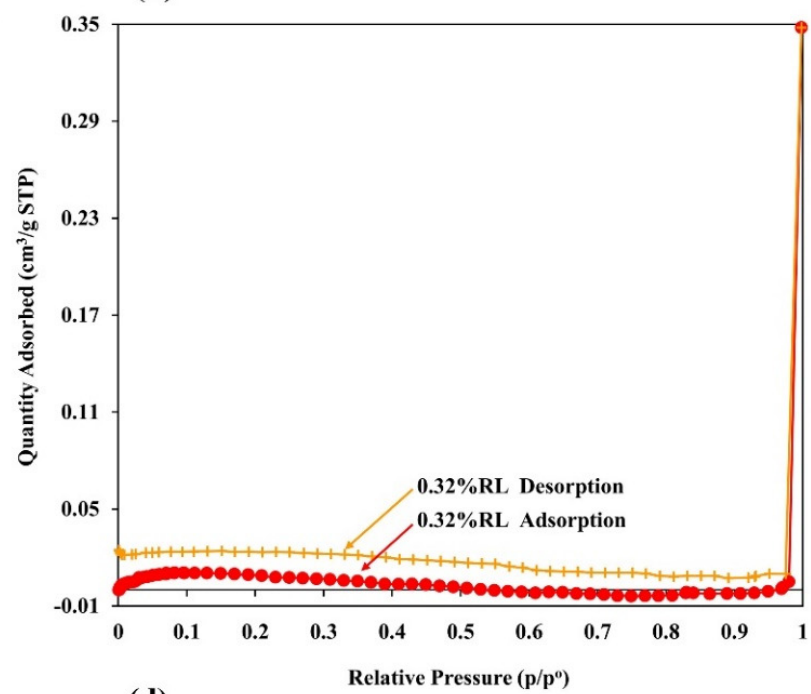

(d)

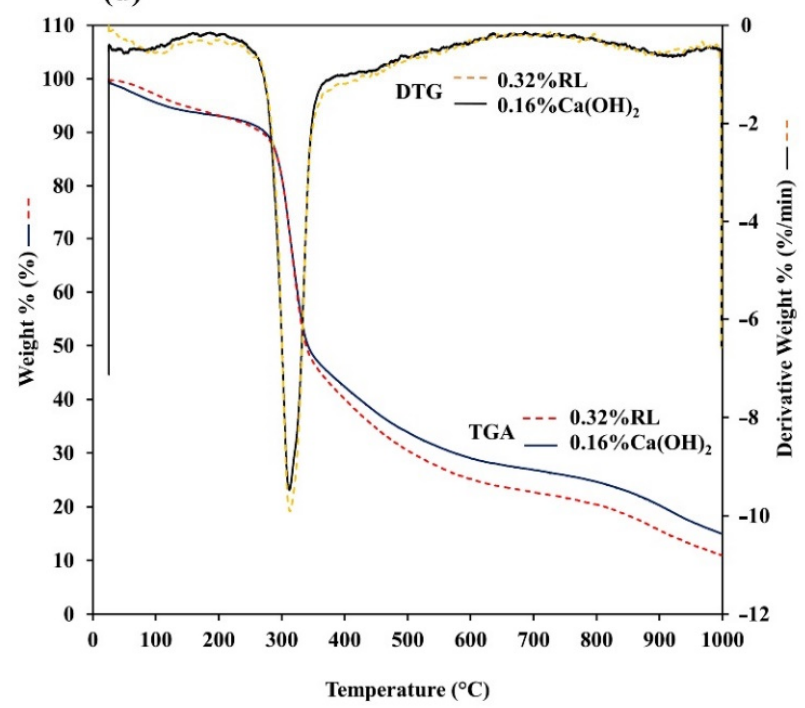

Figure 5. Nitrogen adsorption-desorption isotherms of the cryogels prepared from (a) $0.16 \% \mathrm{Ca}(\mathrm{OH})_{2}$, and (b) $0.32 \% \mathrm{RL}$; (c) XRD and, (d) TGA patterns of the synthesized cryogels.

The XRD patterns of the cryogels prepared with and without $\mathrm{Ca}^{2+}$ revealed a broad hump centered at $2 \theta \sim 20^{\circ}$ (Figure 5c), indicating an amorphous structure. The intense XRD peaks typically present at $2 \theta$ values of $12.2^{\circ}, 15.1^{\circ}, 17^{\circ}, 18.1^{\circ}, 20^{\circ}, 23.1^{\circ}$, and $26.6^{\circ}$ indicate an A-type crystalline structure of rice starch [51], but these were not observed. This is because the crystallinity of the starch granules was disrupted by gelatinization at an elevated temperature [52], as well as the cross-linking with $\mathrm{Ca}^{2+}$. It can be seen that the cryogel prepared from ultrapure water showed small peaks located at $2 \theta \sim 13^{\circ}$ and $2 \theta \sim 20^{\circ}$, which are characteristic of a V-type crystalline structure $[39,51]$. This indicates that some crystallinity remained in the cryogel prepared without $\mathrm{Ca}^{2+}$, while the intensity of these peaks was much reduced in the cryogels with $\mathrm{Ca}^{2+}$. These results suggest that $\mathrm{Ca}^{2+}$ ions also contribute to the loss of crystallinity.

Thermal gravimetric analysis (TGA) of the cryogels prepared from $0.16 \% \mathrm{Ca}(\mathrm{OH})_{2}$ and $0.32 \%$ RL showed similar patterns, exhibiting four main steps from room temperature to $1000{ }^{\circ} \mathrm{C}$ (Figure $5 \mathrm{~d}$ ): The $\sim 10 \%$ weight loss from room temperature to $200{ }^{\circ} \mathrm{C}$ was observed at the first step due to loss of moisture and/or other low-molecular weight compounds [39]. The second step was the major weight loss from 250 to $400{ }^{\circ} \mathrm{C}$, attributed to starch decomposition corresponding to hydroxyl group elimination and carbon chain decomposition 
and depolymerization [39]. The third step occurred at 400 to $600{ }^{\circ} \mathrm{C}$ attributed to $\mathrm{Ca}(\mathrm{OH})_{2}$ dehydroxylation, while the fourth step occurred above $600^{\circ} \mathrm{C}$ indicating the loss of chemically bound $\mathrm{CO}_{2}$ (decarboxylation) from $\mathrm{CaCO}_{3}$ components [39]. Although the thermal stability of the cryogels prepared with $0.16 \% \mathrm{Ca}(\mathrm{OH})_{2}$ and $0.32 \% \mathrm{RL}$ was similar (with maximum degradation rates at $312.1^{\circ} \mathrm{C}$ and $312.6{ }^{\circ} \mathrm{C}$, respectively), the weight loss in the third and the fourth steps of the cryogels prepared with $0.32 \%$ RL was higher than with $0.16 \% \mathrm{Ca}(\mathrm{OH})_{2}$ and this may be attributed to the higher amount of $\mathrm{Ca}(\mathrm{OH})_{2}$ and chemically bound $\mathrm{CO}_{2}$ from $\mathrm{CaCO}_{3}$ components.

All of the cryogels had similar FTIR spectra (Figure 6) and the major bands are summarized in the Supplementary Materials (Table S12). A large band observed at $3286 \mathrm{~cm}^{-1}$ in the cryogels prepared using ultrapure water slightly shifted to a lower absorption frequency of $3284 \mathrm{~cm}^{-1}$ and $3279 \mathrm{~cm}^{-1}$ in the cryogels prepared with $0.16 \% \mathrm{Ca}(\mathrm{OH})_{2}$ and $0.32 \% \mathrm{RL}$, respectively, indicating stronger interactions of $\mathrm{Ca}^{2+}$ with the $-\mathrm{OH}$ groups of starch molecules $[9,53,54]$, with a higher concentration of $\mathrm{Ca}^{2+}$ in the solution (Table 1). Absorption peaks at $2924 \mathrm{~cm}^{-1}$ and $1078 \mathrm{~cm}^{-1}$ were consistent for all cryogels, indicating that the chemical bonds did not suffer any changes. The adsorption peaks at 1638, 1410,1148, 995 , and $930 \mathrm{~cm}^{-1}$ in the cryogels without $\mathrm{Ca}^{2+}$ revealed slight shifts to higher adsorption frequencies of $1642,1415,1150,999$, and $933 \mathrm{~cm}^{-1}$, respectively, in the cryogels with $\mathrm{Ca}^{2+}$. These shifts indicate interactions between the $\mathrm{Ca}^{2+}$ and hydroxy groups of starch molecules that can stabilize these bonds, and may contribute to decreased hydrogen bonding. From the results, since no new chemical bonds were observed in the FTIR spectra of the cryogels prepared with $\mathrm{Ca}^{2+}$, the divalent ions would interact with starch molecules by physical cross-linking via Van der Waals interactions, consistent with previous reports [42].

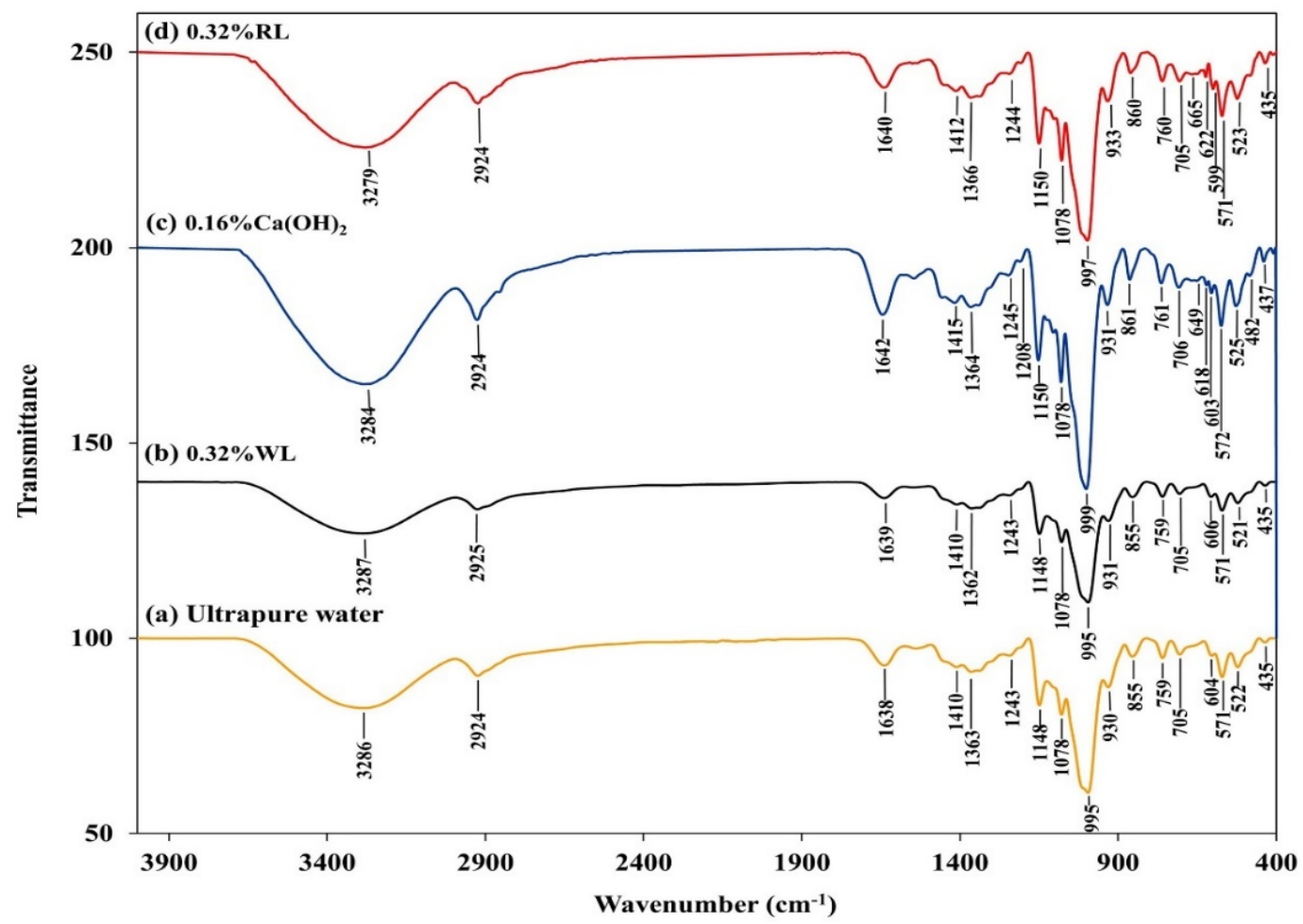

Figure 6. FTIR spectra of the cryogels.

\subsection{Water Uptake Capacity, Swelling Capacity, and Water Retention of Cryogels}

The swelling ratios of the cryogels increased over time at room temperature (Figure 7a). Although the swelling ratio of the $0.16 \% \mathrm{Ca}(\mathrm{OH})_{2}$ cryogel was less than for $0.32 \% \mathrm{RL}$ for 1-5 min, the two ratios were similar after reaching the equilibrium at $10 \mathrm{~min}$ $\left(6.4 \pm 0.6 \mathrm{~g}_{\text {water }} / \mathrm{g}_{\text {cryogel }}\right.$ for $0.16 \% \mathrm{Ca}(\mathrm{OH})_{2}$ and $6.0 \pm 0.3 \mathrm{~g}_{\text {water }} / \mathrm{g}_{\text {cryogel }}$ for $\left.0.32 \% \mathrm{RL}\right)$. Both 
cryogels had swelling capacity similar to that in a previous report, namely, 3.2 to $5.5 \mathrm{~g} / \mathrm{g}$ for polyacrylamide cryogel [11], which is much less than for a conventional gel prepared at ambient temperature. It has been reported that the swelling degree of cryogels is less than that of hydrogels prepared under similar conditions except for the higher temperatures, by at least 3-6-fold [55], or as much as 930-fold [15]. The low swelling ratio of the prepared cryogels makes them suitable for application as filters.

The swelling ratio of both cryogels seemed to be constant for a wide $\mathrm{pH}$ range, but not under strongly alkaline conditions ( $\mathrm{pH} 13$ ) (Figure $7 \mathrm{~b}$ ). The $\mathrm{pH}$-independent swelling of the cryogels might relate to the physical cross-linking with $\mathrm{Ca}^{2+}$ ions around the hydroxyl groups in the cryogel network, which may limit the additional cross-linking from ions in the solution. The dramatic increase in swelling ratio at high $\mathrm{pH}$ may be attributed to the loss of the physical cross-linking between $\mathrm{Ca}^{2+}$ ions and the hydroxyl groups in the cryogel network. The results indicate that the material could be applied in a wide $\mathrm{pH}$ range without changes in swelling properties. The swelling ratio of both cryogels increased with temperatures (as discussed in the Supplementary Materials (Figure S13) consistent with previous reports $[10,56]$.
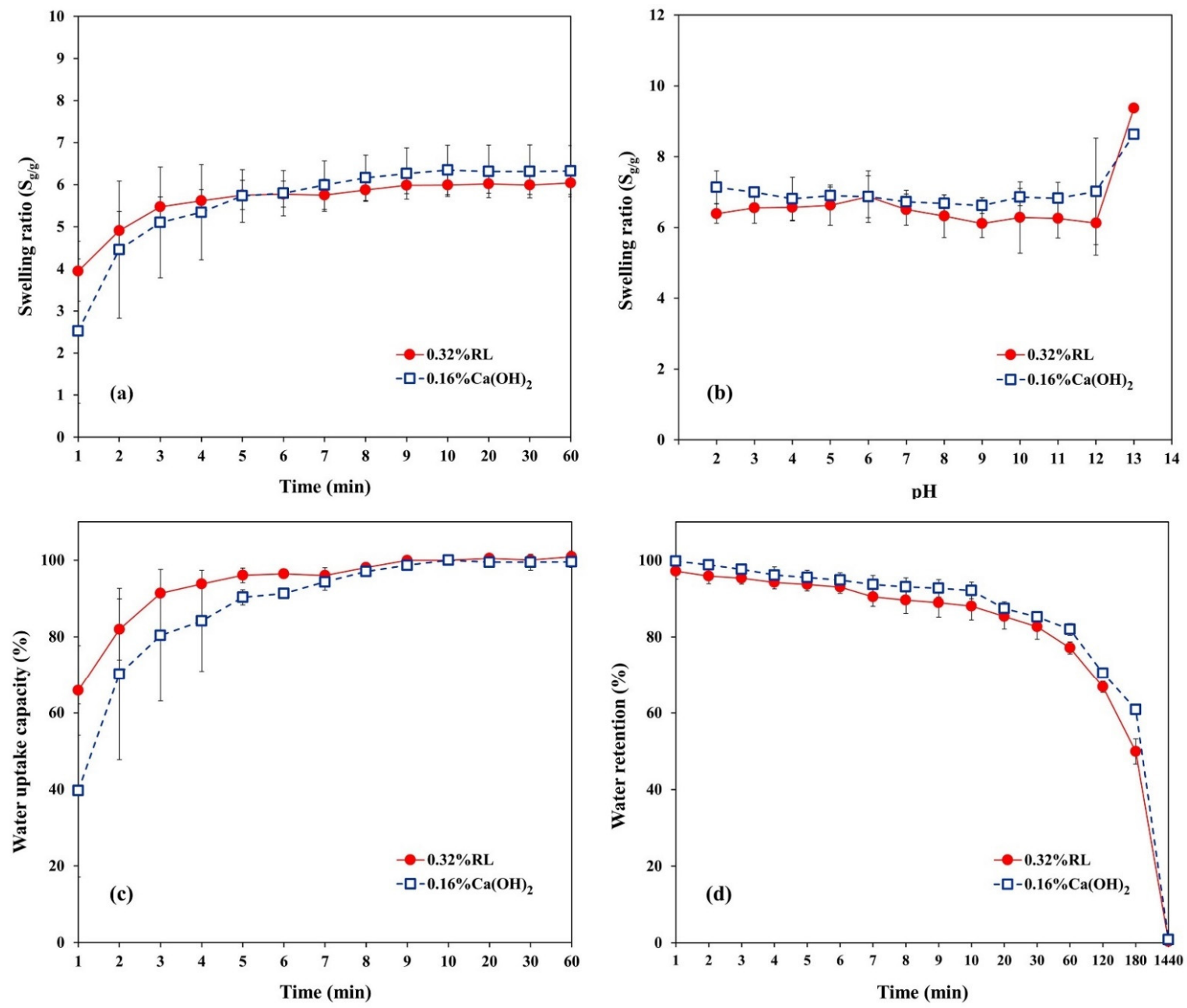

Figure 7. Swelling behavior of the cryogels prepared using $0.32 \% \mathrm{RL}$ and $0.16 \% \mathrm{Ca}(\mathrm{OH})_{2}(n=3)(\mathbf{a})$ swelling ratio, (b) effects of $\mathrm{pH},(\mathbf{c})$ water uptake capacity, and (d) water retention.

The cryogels prepared from $0.32 \%$ RL could adsorb water for $599 \pm 27 \%$ of the dry weight, while $635 \pm 59 \%$ was recorded for the $0.16 \% \mathrm{Ca}(\mathrm{OH})_{2}$ cryogel after $10 \mathrm{~min}$ (Figure 7c). The water retention abilities of both cryogels decreased over time (Figure 7d). The $0.32 \%$ RL cryogel lost $50 \%$ of adsorbed water in $3 \mathrm{~h}$, more than the $0.16 \% \mathrm{Ca}(\mathrm{OH})_{2}$ 
cryogel which lost $39 \%$. Moreover, the latter showed higher water retention than the former. As discussed in connection with the FTIR results, the interaction between the $\mathrm{Ca}^{2+}$ and $-\mathrm{OH}$ groups of starch molecules in the $0.32 \% \mathrm{RL}$ cryogel was stronger than $0.16 \% \mathrm{Ca}(\mathrm{OH})_{2}$ cryogel, due to the higher concentration of $\mathrm{Ca}^{2+}$. The hydrogen bonding between water and the hydroxyl groups which delayed the evaporation of water in the $0.32 \%$ RL cryogel was thus less than in the $0.16 \% \mathrm{Ca}(\mathrm{OH})_{2}$ cryogel, causing the lower water retention.

\subsection{Swelling Kinetics of Cryogels}

The swelling kinetics of the cryogels were investigated and are discussed in the Supplementary Materials (Figure S10). The theoretical equilibrium swelling ratio (Seq) for the $0.16 \% \mathrm{Ca}(\mathrm{OH})_{2}$ cryogel was higher than that for the $0.32 \%$ RL cryogel, with a lower swelling rate constant $(\mathrm{ks})$ and lower initial swelling rate $\left(\mathrm{r}_{\mathrm{i}}\right)$ (Supplementary Materials, Table S15). These were close to the experimental swelling ratios at equilibrium at $10 \mathrm{~min}$. The higher initial swelling rate of $0.32 \%$ RL also matched the experimental results in Figure 7a.

The swelling mechanism of the cryogels was also determined and is discussed in the Supplementary Materials (Figures S16 and S17). Due to the swelling exponent $n \leq 0.5$ for both cryogels (Supplementary Materials, Table S15), there was Fickian diffusion with a slower rate of water diffusion than the polymer relaxation rate [44], causing a low swelling capacity for both cryogels. The diffusion coefficient of water through the $0.16 \% \mathrm{Ca}(\mathrm{OH})_{2}$ cryogel was higher than for the $0.32 \%$ RL cryogel, indicating faster diffusion of water in $0.16 \% \mathrm{Ca}(\mathrm{OH})_{2}$ leading to a greater swelling ratio.

\subsection{Application of Cryogels as Filters}

Both cryogels were preliminarily tested as filters for five water samples, and showed the ability to reduce the light absorption of the samples at specific wavelengths (Table 2 and Supplementary Materials, Figure S18). The maximum adsorption at $285-290 \mathrm{~nm}$ of these samples decreased from $25 \pm 3$ to $94 \pm 6 \%$ and from $27 \pm 4$ to $96 \pm 5 \%$ when filtered through the filters prepared from $0.16 \% \mathrm{Ca}(\mathrm{OH})_{2}$ and $0.32 \% \mathrm{RL}$, respectively. It can be seen that the suspended particles in the samples were filtered off (Figure 8a,b). The water samples could also be easily filtered using gravity flow without any need for a vacuum pump, as the prepared filters contained interconnected macropores. In addition, they could be easily cleaned by flushing with reversed flow and washing with ultrapure water, and could be re-used up to three times with $\sim 24 \%$ difference to the first use (Figure 8 c). These filters cost only THB 0.01 (USD 0.0004) per item as tested, and pose no risk to the environment, so they can also safely be discarded after a single use. These results indicate that the cryogels could have environmental applications.

Table 2. The absorbance of aqueous suspension samples before and after filtering with the prepared filters.

\begin{tabular}{|c|c|c|c|c|c|c|}
\hline \multirow{2}{*}{ Sample } & \multirow{2}{*}{ Type } & \multicolumn{3}{|c|}{ Absorbance at $\lambda_{\text {MAX }}(290 \mathrm{~nm})$} & \multicolumn{2}{|c|}{ \%Reduction } \\
\hline & & before & after $0.32 \% R L$ & after $0.16 \% \mathrm{Ca}(\mathrm{OH})_{2}$ & $0.32 \% \mathrm{RL}$ & $0.16 \% \mathrm{Ca}(\mathrm{OH})_{2}$ \\
\hline 1 & Surface water & $0.192 \pm 0.005$ & $0.069 \pm 0.005$ & $0.078 \pm 0.008$ & $64 \pm 3$ & $59 \pm 5$ \\
\hline 2 & Surface water & $0.111 \pm 0.006$ & $0.004 \pm 0.005$ & $0.007 \pm 0.006$ & $96 \pm 5$ & $94 \pm 6$ \\
\hline 3 & Surface water & $0.193 \pm 0.006$ & $0.098 \pm 0.003$ & $0.100 \pm 0.002$ & $49 \pm 1$ & $48 \pm 2$ \\
\hline 4 & Surface water & $1.148 \pm 0.032$ & $0.836 \pm 0.038$ & $0.856 \pm 0.021$ & $27 \pm 4$ & $25 \pm 3$ \\
\hline 5 & Soil extract & $0.886 \pm 0.129$ & $0.319 \pm 0.047$ & $0.430 \pm 0.064$ & $63 \pm 10$ & $51 \pm 9$ \\
\hline
\end{tabular}


(a)

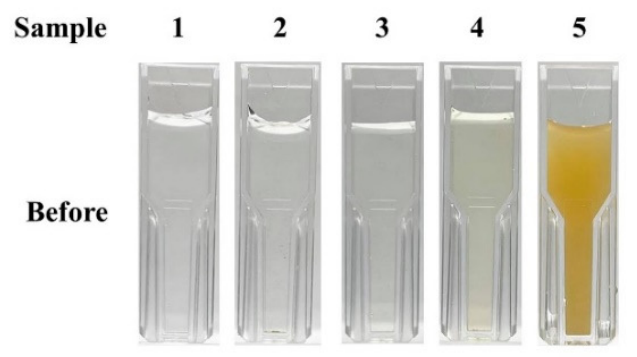

After $0.16 \% \mathrm{Ca}(\mathrm{OH})_{2}$
\%Reduction

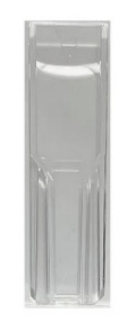

\%Reduction

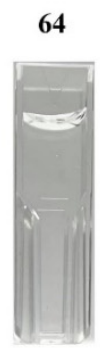

59

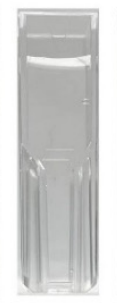

96

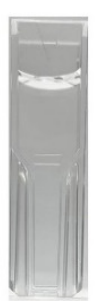

94
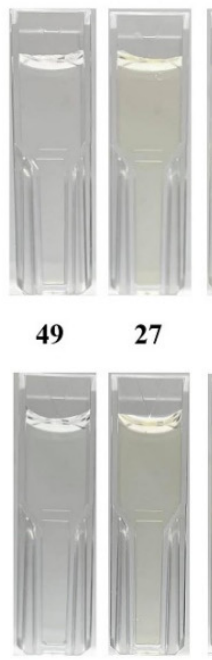

48 (b)
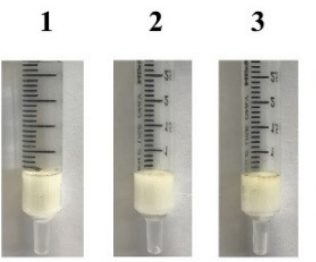

45

After $0.32 \%$ RL

After

$0.16 \% \mathrm{Ca}(\mathrm{OH})_{2}$
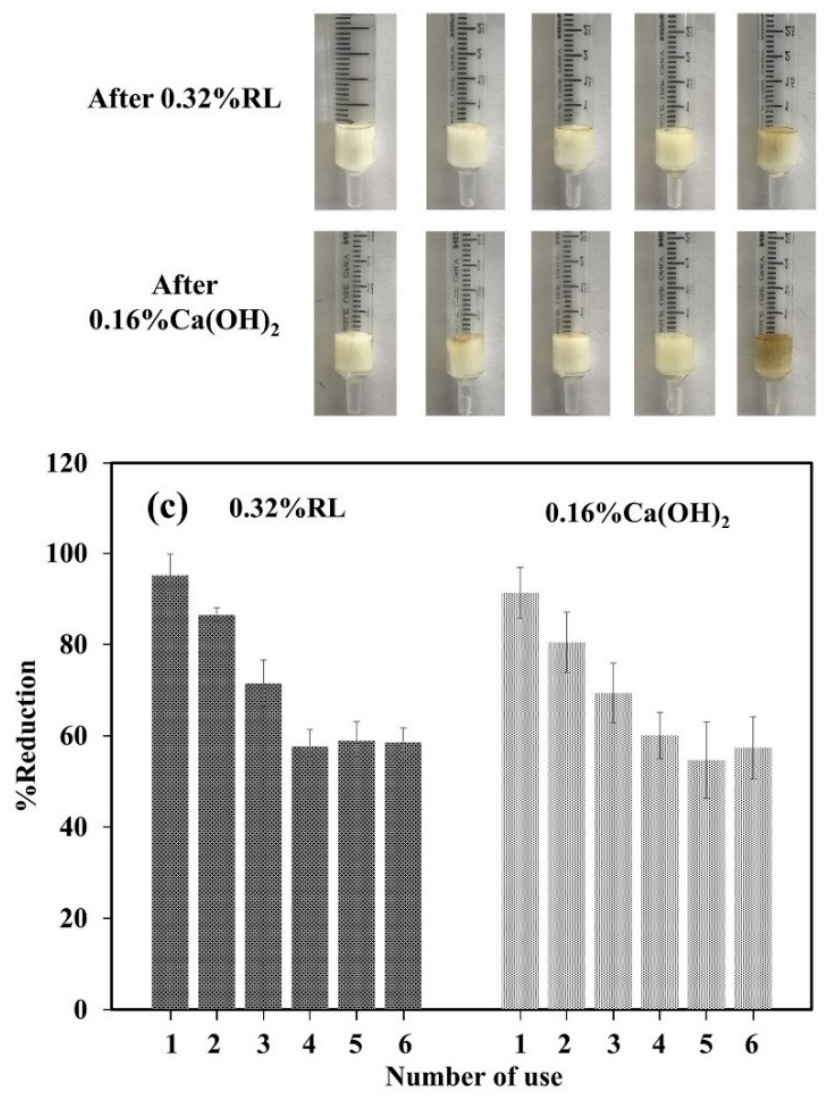

Figure 8. (a) Real water samples before and after filtering through the cryogels; (b) the cryogels after used to filter real samples; (c) reusability of the filters.

\subsection{Biodegradation of Cryogels}

Biodegradation of the cryogels was investigated using a soil burial test and it was found that both cryogels lost $100 \%$ of their weight when buried in the soil for 30 days (Supplementary Materials, Figure S19) due to hydrolysis and microorganisms [33].

\section{Conclusions}

The procedure to prepare the traditional dessert "Lod-chong" in conjunction with conventional freeze thaw techniques can be applied as an alternative method to prepare starch-based cryogels. Rice flour was used as the natural starch polymer source without any need of a synthetic polymer, while limewater acted as the cross-linker. The $\mathrm{Ca}^{2+}$ ions of the latter physically cross-linked with $\mathrm{OH}$ groups in starch via Van der Waals interactions. Macropores evidenced in the prepared cryogels (51 \pm 18 to $52 \pm 15 \mu \mathrm{m})$ could facilitate porous flow in applications as filters and/or adsorbents to remove some particles and substances from water. The low swelling capacity of the cryogels $(6.0 \pm 0.3$ to $\left.6.4 \pm 0.6 \mathrm{~g}_{\text {water }} / \mathrm{g}_{\text {cryogel }}\right)$ could be a benefit when used as filters, as well as in some other applications. The material can be easily cleaned and re-used up to three times, and is completely biodegraded when buried in the soil for 30 days. The cryogels reported in the work are thus an attractive choice as cost-effective green materials prepared via a simple procedure. Other types of environmental applications in the removal of environ-mental pollutants are under investigation, and the results will be reported in the future. 
Supplementary Materials: The following are available online at https:/ / www.mdpi.com/article/10 .3390 / polym13223975/s1: Figure S1: FTIR spectra of white lime (WL), red lime (RL), and calcium hydroxide standard $\left(\mathrm{Ca}(\mathrm{OH})_{2}\right)$; Figure S2: XRD patterns of red lime (RL), white lime (WL), and calcium hydroxide standard $\left(\mathrm{Ca}(\mathrm{OH})_{2}\right)$; Figure S3: $\mathrm{pH}$ of calcium hydroxide solutions before and during mixing with starch while heated, and after stopping heating, with various amounts of red lime $(\mathrm{RL})$, white lime $(\mathrm{WL})$, and calcium hydroxide standard solution $\left(\mathrm{Ca}(\mathrm{OH})_{2}\right)(n=3)$; Figure S4: $\mathrm{pH}$ of limewater with various amounts of red lime (RL), white lime (WL), and calcium hydroxide standard solution $\left(\mathrm{Ca}(\mathrm{OH})_{2}\right)$ for 28 days after preparation $(n=3)$; Figure S5: Preparation of cryogels from rice starch (right) and Lod-chong noodles (left); Figure S6: (a) Images of the synthesized cryogels from $0.32 \% \mathrm{WL}, 0.32 \% \mathrm{RL}$, and $0.16 \% \mathrm{Ca}(\mathrm{OH})_{2}$ using $1-7$ freeze- thaw cycles; (b) FE-SEM images of $0.32 \%$ RL cryogels with 1-7 freeze thaw-cycles; Figure S7: Porosity of the synthesized cryogels using 1-7 freeze- thaw cycles; Figure S8: Images of cryogels prepared using $0.32 \%$ RL (a) after thawing (left), after drying without (middle) and with (right) soaking in ethanol; (b) top view of the ethanol dehydrated cryogel (left) and re-swollen cryogel (right); and (c) side view of the ethanol dehydrated cryogel (left) and re-swollen cryogel (right); Figure S9: FE-SEM images and the average wall thicknesses of (a) $0.32 \% \mathrm{RL}$ and (b) $0.16 \% \mathrm{Ca}(\mathrm{OH})_{2}$ cryogels when dried via freeze-drying; Figure S10: Weight change of the cryogels before and after soaking in ethanol for various incubation times; Figure S11: Porosity of the cryogels dried via ethanol dehydration and via freeze-drying; Table S12: Major FTIR bands in the cryogels [42,52-54]; Figure S13: Effect of temperature on the swelling ratios of cryogels prepared using $0.32 \% \mathrm{RL}$ and $0.16 \% \mathrm{Ca}(\mathrm{OH})_{2}$; Figure S14: Relationship between $t / S$ and $t$ from investigation of the swelling kinetics of the cryogels; Table S15: Swelling and diffusion characteristics of the cryogels $(n=3)$; Figure S16: Relationship between $\ln \mathrm{S}_{\mathrm{F}}$ and $\ln \mathrm{t}$ from investigation of the swelling mechanisms of the cryogels; Figure S17: Diffusion curves of the prepared cryogels; Figure S18: Absorption spectra of water samples before and after filtration using the prepared filters; Figure S19: \%Weight remaining of the prepared cryogels after burial in soil for 30 days.

Author Contributions: Conceptualization, A.C., C.B. and W.W.; methodology, A.C., C.B. and W.W.; validation, A.C., C.B. and W.W.; formal analysis, A.C. and C.B.; investigation, C.B., K.P., N.L. and T.T.; resources, A.C. and W.W.; data curation, A.C., C.B., L.C. and W.W.; writing-original draft preparation, A.C., C.B. and W.W.; writing-review and editing, A.C. and W.W.; visualization, C.B.; supervision, A.C. and W.W.; project administration, A.C.; funding acquisition, A.C., C.B. and W.W. All authors have read and agreed to the published version of the manuscript.

Funding: This work was supported by the National Research Council of Thailand (NRCT) through the research grant no. NRCT5-RSA63022-05 and the Royal Golden Jubilee Ph.D. Programme (RGJ) [Grant No. PHD/0156/2559] for C.B.

Institutional Review Board Statement: Not applicable.

Informed Consent Statement: Not applicable.

Data Availability Statement: All data are available from the corresponding author on reasonable request.

Acknowledgments: The authors would like to thank the support for article processing charge from Prince of Songkla University and the Royal Golden Jubilee Ph.D. Programme (RGJ).

Conflicts of Interest: There is no conflict to declare.

\section{References}

1. Henderson, T.M.A.; Ladewig, K.; Haylock, D.N.; McLean, K.M.; O'Connor, A.J. Cryogels for biomedical applications. J. Mater. Chem. B 2013, 1, 2682-2695. [CrossRef] [PubMed]

2. Eggermont, L.J.; Rogers, Z.J.; Colombani, T.; Memic, A.; Bencherif, S.A. Injectable cryogels for biomedical applications. Trends Biotechnol. 2020, 38, 418-431. [CrossRef] [PubMed]

3. Hixon, K.; Lu, T.; Sell, S.A. A comprehensive review of cryogels and their roles in tissue engineering applications. Acta Biomater. 2017, 62, 29-41. [CrossRef] [PubMed]

4. Baimenov, A.; Berillo, D.A.; Poulopoulos, S.G.; Inglezakis, V.J. A review of cryogels synthesis, characterization and applications on the removal of heavy metals from aqueous solutions. Adv. Colloid Interface Sci. 2020, 276, 102088. [CrossRef] [PubMed]

5. Gun'ko, V.M.; Savina, I.N.; Mikhalovsky, S.V. Cryogels: Morphological, structural and adsorption characterisation. Adv. Colloid Interface Sci. 2013, 187-188, 1-46. [CrossRef] 
6. Ertürk, G.; Mattiasson, B. Cryogels-versatile tools in bioseparation. J. Chromatogr. A 2014, 1357, 24-35. [CrossRef]

7. Dainiak, M.B.; Kumar, A.; Galaev, I.Y.; Mattiasson, B. Detachment of affinity-captured bioparticles by elastic deformation of a macroporous hydrogel. Proc. Natl. Acad. Sci. USA 2006, 103, 849-854. [CrossRef]

8. Galaev, I.Y.; Dainiak, M.B.; Plieva, F.; Mattiasson, B. Effect of matrix elasticity on affinity binding and release of bioparticles. Elution of bound cells by temperature-induced shrinkage of the smart macroporous hydrogel. Langmuir 2007, 23, 35-40. [CrossRef]

9. Plieva, F.M.; Karlsson, M.; Aguilar, M.R.; Gomez, D.; Mikhalovsky, S.; Galaev', I.Y. Pore structure in supermacroporous polyacrylamide based cryogels. Soft Matter 2005, 1, 303-309. [CrossRef]

10. Nakamatsu, J.; Torres, F.G.; Troncoso, O.P.; Min-Lin, Y.; Boccaccini, A.R. Processing and characterization of porous structures from chitosan and starch for tissue engineering scaffolds. Biomacromolecules 2006, 7, 3345-3355. [CrossRef]

11. Plieva, F.M.; Galaev, I.Y.; Mattiasson, B. Macroporous gels prepared at subzero temperatures as novel materials for chromatography of particulate-containing fluids and cell culture applications. J. Sep. Sci. 2007, 30, 1657-1671. [CrossRef]

12. Mattiasson, B.; Kumar, A.; Galaev, I.Y. Macroporous Polymers: Production Properties and Biotechnological/Biomedical Applications. In Macroporous Polymers: Production Properties and Biotechnological/Biomedical Applications; CRC Press: Boca Raton, FL, USA, 2009.

13. Cui, Z. Medical Biotechnology and Healthcare. In Comprehensive Biotechnology; Elsevier: Amsterdam, The Netherlands, 2011.

14. Kumar, A. Supermacroporous Cryogels: Biomedical and Biotechnological Applications. In Supermacroporous Cryogels: Biomedical and Biotechnological Applications; CRC Press: Boca Raton, FL, USA, 2016.

15. Rac, V.; Lević, S.; Balanč, B.; Graells, B.O.; Bijelic, G. PVA Cryogel as model hydrogel for iontophoretic transdermal drug delivery investigations. Comparison with PAA/PVA and PAA/PVP interpenetrating networks. Colloids Surf. B 2019, 180, 441-448. [CrossRef] [PubMed]

16. Choodum, A.; Kanatharana, P.; Wongniramaikul, W.; Daéid, N.N. Poly vinyl alcohol cryogel as a selective test kit for pre and post blast trinitrotoluene. Sens. Actuators B Chem. 2016, 222, 654-662. [CrossRef]

17. Sahiner, N.; Yildiz, S. Preparation of superporous poly(4-vinyl pyridine) cryogel and their templated metal nanoparticle composites for $\mathrm{H} 2$ production via hydrolysis reactions. Fuel Process. Technol. 2014, 126, 324-331. [CrossRef]

18. Erdem, A.; Ngwabebhoh, F.A.; Çetintaş, S.; Bingöl, D.; Yildiz, U. Fabrication and characterization of novel macroporous Jeffamine/diamino hexane cryogels for enhanced $\mathrm{Cu}(\mathrm{II})$ metal uptake: Optimization, isotherms, kinetics and thermodynamic studies. Chem. Eng. Res. Des. 2017, 117, 122-138. [CrossRef]

19. Kaczmarek, B.; Sionkowska, A.; Osyczka, A.M. The application of chitosan/collagen/hyaluronic acid sponge cross-linked by dialdehyde starch addition as a matrix for calcium phosphate in situ precipitation. Int. J. Biol. Macromol. 2018, 107, 470-477. [CrossRef] [PubMed]

20. Mu, C.; Liu, F.; Cheng, Q.; Li, H.; Wu, B.; Zhang, G.; Lin, W. Collagen Cryogel Cross-Linked by Dialdehyde Starch. Macromol. Mater. Eng. 2010, 295, 100-107. [CrossRef]

21. Sionkowska, A.; Michalska-Sionkowska, M.; Walczak, M. Preparation and characterization of collagen/hyaluronic acid/chitosan film crosslinked with dialdehyde starch. Int. J. Biol. Macromol. 2020, 149, 290-295. [CrossRef]

22. Skopinska-Wisniewska, J.; Wegrzynowska-Drzymalska, K.; Bajek, A.; Maj, M.; Sionkowska, A. Is dialdehyde starch a valuable cross-linking agent for collagen/elastin based materials? J. Mater. Sci. Mater. Med. 2016, 27, 67. [CrossRef]

23. Tan, H.; Wu, B.; Li, C.; Mu, C.; Li, H.; Lin, W. Collagen cryogel cross-linked by naturally derived dialdehyde carboxymethyl cellulose. Carbohydr. Polym. 2015, 129, 17-24. [CrossRef]

24. Chang, K.H.; Liao, H.T.; Chen, J.P. Preparation and characterization of gelatin/hyaluronic acid cryogels for adipose tissue engineering: In vitro and in vivo studies. Acta Biomater. 2013, 9, 9012-9026. [CrossRef] [PubMed]

25. Kutlusoy, T.; Oktay, B.; Apohan, N.K.; Süleymanoğlu, M.; Kuruca, S.E. Chitosan-co-Hyaluronic acid porous cryogels and their application in tissue engineering. Int. J. Biol. Macromol. 2017, 103, 366-378. [CrossRef]

26. Suner, S.S.; Demirci, S.; Yetiskin, B.; Fakhrullin, R.; Naumenko, E.; Okay, O.; Ayyala, R.S.; Sahiner, N. Cryogel composites based on hyaluronic acid and halloysite nanotubes as scaffold for tissue engineering. Int. J. Biol. Macromol. 2019, 130, 627-635. [CrossRef]

27. Tripathi, A.; Kumar, A. Multi-featured macroporous agarose-alginate cryogel: Synthesis and characterization for bioengineering applications. Macromol. Biosci. 2011, 11, 22-35. [CrossRef] [PubMed]

28. Ciolacu, D.; Rudaz, C.; Vasilescu, M.; Budtova, T. Physically and chemically cross-linked cellulose cryogels: Structure, properties and application for controlled release. Carbohydr. Polym. 2016, 151, 392-400. [CrossRef] [PubMed]

29. Guan, Y.; Zhang, B.; Bian, J.; Peng, F.; Sun, R.C. Nanoreinforced hemicellulose-based hydrogels prepared by freeze-thaw treatment. Cellulose 2014, 21, 1709-1721. [CrossRef]

30. Loghin, D.F.A.; Biliuta, G.; Coseri, S.; Dragan, E.S. Preparation and characterization of oxidized starch/poly(N,Ndimethylaminoethyl methacrylate) semi-IPN cryogels and in vitro controlled release evaluation of indomethacin. Int. J. Biol. Macromol. 2017, 96, 589-599. [CrossRef]

31. Dragan, E.S.; Loghin, D.F.A. Enhanced sorption of methylene blue from aqueous solutions by semi-IPN composite cryogels with anionically modified potato starch entrapped in PAAm matrix. Chem. Eng. Sci. 2013, 234, 211-222. [CrossRef]

32. Reis, A.V.; Guilherme, M.R.; Moia, T.A.; Mattoso, L.H.C.; Muniz, E.C.; Tambourgi, E.B. Synthesis and characterization of a starch-modified hydrogel as potential carrier for drug delivery system. J. Polym. Sci. A Polym. Chem. 2008, 46, 2567-2574. [CrossRef] 
33. Junlapong, K.; Maijan, P.; Chaibundit, C.; Chantarak, S. Effective adsorption of methylene blue by biodegradable superabsorbent cassava starch-based hydrogel. Int. J. Biol. Macromol. 2020, 158, 258-264. [CrossRef]

34. Zou, F.; Budtova, T. Tailoring the morphology and properties of starch aerogels and cryogels via starch source and process parameter. Carbohydr. Polym. 2021, 255, 117344. [CrossRef] [PubMed]

35. Coria-Hernández, J.; Méndez-Albores, A.; Meléndez-Pérez, R.; Rosas-Mendoza, M.E.; Arjona-Román, J.L. Thermal, Structural, and Rheological Characterization of Waxy Starch as a Cryogel for Its Application in Food Processing. Polymers 2018, 10, 359. [CrossRef] [PubMed]

36. Pookidakan, P.; Jangchud, K. Preference Mapping of Pandan Noodles for Thai Lod-Chong. In Proceedings of the 16th Food Innovation Asia Conference 2014: Science and Innovation for Quality of Life, Bangkok, Thailand, 12-13 June 2014; pp. 779-787.

37. Jayaramudu, T.; Ko, H.U.; Kim, H.C.; Kim, J.W.; Kim, J. Swelling Behavior of Polyacrylamide-Cellulose Nanocrystal Hydrogels: Swelling Kinetics, Temperature, and pH Effects. Materials 2019, 12, 2080. [CrossRef] [PubMed]

38. Xue, W.; Champ, S.; Huglin, M.B.; Jones, T.G.J. Rapid swelling and deswelling in cryogels of crosslinked poly(Nisopropylacrylamide-co-acrylic acid). Eur. Polym. J. 2004, 40, 467-476. [CrossRef]

39. Bryant, C.; Hamaker, B. Effect of Lime on Gelatinization of Corn Flour and Starch. Cereal Chem. 1997, 74, 171-175. [CrossRef]

40. Chanjarujit, W.; Hongsprabhas, P.; Chaiseri, S. Physicochemical properties and flavor retention ability of alkaline calcium hydroxide-mungbean starch film. Carbohydr. Polym. 2018, 198, 473-480. [CrossRef]

41. Israkarn, K.; Hongsprabhas, P. Effect of $\mathrm{CaCl} 2$ on the formation of Ca-induced starch aggregates and spherulitic structure in dried starch film. Dry. Technol. 2017, 35, 1552-1560. [CrossRef]

42. Cornejo-Villegas, M.Á.; Rincón-Londoño, N.; Real-López, A.D.; Rodríguez-García, M.E. The effect of Ca2+ ions on the pasting, morphological, structural, vibrational, and mechanical properties of corn starch-water system. J. Cereal Sci. 2018, 79, 174-182. [CrossRef]

43. Chau, M.; De France, K.J.; Kopera, B.; Machado, V.R.; Rosenfeldt, S.; Reyes, L.; Chan, K.J.W.; Förster, S.; Cranston, E.D.; Hoare, T.; et al. Composite Hydrogels with Tunable Anisotropic Morphologies and Mechanical Properties. Chem. Mater. 2016, 28, 3406-3415. [CrossRef]

44. Bajpai, A.K.; Shrivastava, M. Swelling kinetics of a hydrogel of poly(ethylene glycol) and poly(acrylamide-co-styrene). J. Appl. Polym. Sci. 2002, 85, 1419-1428. [CrossRef]

45. Wang, S.; Li, C.; Yu, J.; Copeland, L.; Wang, S. Phase transition and swelling behaviour of different starch granules over a wide range of water content. LWT-Food Sci. Technol. 2014, 59, 597-604. [CrossRef]

46. Lozinsky, V.; Okay, O. Basic Principles of Cryotropic Gelation. Adv. Polym. Sci. 2014, 263, 49-101. [CrossRef]

47. Baudron, V.; Gurikov, P.; Smirnova, I.; Whitehouse, S. Porous Starch Materials via Supercritical- and Freeze-Drying. Gels 2019, 5 , 12. [CrossRef] [PubMed]

48. Thommes, M.; Kaneko, K.; Neimark, A.V.; Olivier, J.P.; Rodriguez-Reinoso, F.; Rouquerol, J.; Sing, K.S.W. Physisorption of gases, with special reference to the evaluation of surface area and pore size distribution (IUPAC Technical Report). Pure Appl. Chem. 2015, 87, 1051-1069. [CrossRef]

49. Qi, L.; Xu, T.; Wang, Z.; Peng, X. Pore characterization of different types of coal from coal and gas outburst disaster sites using low temperature nitrogen adsorption approach. Int. J. Min. Sci. Technol. 2017, 27, 371-377. [CrossRef]

50. Domene-López, D.; García-Quesada, J.C.; Martin-Gullon, I.; Montalbán, M.G. Influence of Starch Composition and Molecular Weight on Physicochemical Properties of Biodegradable Films. Polymers 2019, 11, 1084. [CrossRef]

51. Wang, S.; Zhang, X.; Wang, S.; Copeland, L. Changes of multi-scale structure during mimicked DSC heating reveal the nature of starch gelatinization. Sci. Rep. 2016, 6, 28271. [CrossRef]

52. Jiang, X.; Jiang, T.; Gan, L.; Zhang, X.; Dai, H.; Zhang, X. The plasticizing mechanism and effect of calcium chloride on starch/poly(vinyl alcohol) films. Carbohydr. Polym. 2012, 90, 1677-1684. [CrossRef]

53. Boonkanon, C.; Phatthanawiwat, K.; Wongniramaikul, W.; Choodum, A. Curcumin nanoparticle doped starch thin film as a green colorimetric sensor for detection of boron. Spectrochim. Acta A Mol. Biomol. Spectrosc. 2020, 224, 117351. [CrossRef]

54. Wongniramaikul, W.; Limsakul, W.; Choodum, A. A biodegradable colorimetric film for rapid low-cost field determination of formaldehyde contamination by digital image colorimetry. Food Chem. 2018, 249, 154-161. [CrossRef]

55. Gupta, N.V.; Shivakumar, H.G. Investigation of Swelling Behavior and Mechanical Properties of a pH-Sensitive Superporous Hydrogel Composite. Iran. J. Pharm. Res. 2012, 11, 481-493, PMCID:PMC3832170. [PubMed]

56. Basavarajappa, S.; Perea-Lowery, L.; Aati, S.; Al-Kheraif, A.A.A.; Ramakrishnaiah, R.; Matinlinna, J.P.; Vallittu, P.K. The effect of ethanol on surface of semi-interpenetrating polymer network (IPN) polymer matrix of glass-fibre reinforced composite. J. Mech. Behav. Biomed. Mater. 2019, 98, 1-10. [CrossRef] [PubMed] 